\title{
Profil Darah Tepi pada Anak dengan Infeksi Dengue
}

\author{
Citra Raditha, Alan Roland Tumbelaka, Irawan Mangunatmadja, Taralan Tambunan, \\ Najib Advani, Rosalina Roeslani \\ Departemen Ilmu Kesehatan Anak Fakultas Kedokteran Universitas Indonesia/Rumah Sakit Cipto \\ Mangunkusumo, Jakarta
}

\begin{abstract}
Latar belakang. Infeksi dengue merupakan infeksi Arbovirus tersering pada manusia. Insiden global dari infeksi ini telah meningkat secara dramatis dalam beberapa dekade terakhir. Perjalanan penyakit sulit diperkirakan, dan derajat penyakit bervariasi mulai dari yang bersifat asimtomatik sampai dengan syok.

Tujuan. Mengetahui hubungan antara kombinasi parameter darah tepi dengan derajat infeksi dengue pada saat time of fever defervescence.

Metode. Penelitian deskriptif analitik pada anak sepsis umur 1-18 tahun yang dirawat di Departemen. Ilmu Kesehatan Anak FKUI-RSUPN Cipto Mangunkusumo, RS Fatmawati, dan RS Harapan Kita. Penelitian dilakukan dari November 2010 - April 2011. Pemeriksaan darah tepi berupa trombosit, leukosit, hemoglobin, hematokrit, dan limfosit plasma biru dilakukan secara berkala tiap hari, dan pemeriksaan serologi hari ke-5 demam pada setiap subjek. Selanjutnya dilakukan analisis hubungan kombinasi parameter darah tepi dengan derajat infeksi dengue pada saat time of fever defervescence.

Hasil. Terdapat 100 subyek penelitian, terdiri dari 50 DD, 30 DBD derajat I dan II, dan 20 SSD antara bulan November 2010-April 2011. Pada demam hari ke-3, terjadi penurunan jumlah trombosit, leukosit, serta peningkatan nilai hemoglobin, dan hematokrit. Jumlah limfosit plasma biru mengalami peningkatan sejak awal demam. Analisis diskriminan menemukan persamaan antara kombinasi trombosit, hematokrit, leukosit dengan derajat berat infeksi dengue pada saat time of fever defervescence yaitu $y=-6,089-0,020$ $\mathrm{x}$ trombosit $\left(\right.$ dalam $\left.10^{3}\right)+0,152 \times$ hematokrit $+0,22 \times$ leukosit (dalam $\left.10^{3}\right)$. Prediksi diagnosis DD jika memiliki nilai diskriminasi $-3,06047$ hingga -0,20671, DBD derajat I-II jika nilai diskriminasi -0,25809 hingga 0,78855, dan SSD jika nilai diskriminasi 0,45226 hingga 2,80560.

Kesimpulan. Penelitian ini menemukan hubungan antara kombinasi trombosit, hematokrit, leukosit dengan derajat berat infeksi dengue pada saat time of fever defervescence. Sari Pediatri 2013;15(1):23-6.
\end{abstract}

Kata kunci: dengue, trombosit, leukosit, hemoglobin, hematokrit, limfosit plasma biru, defervescence.

Alamat korespondensi:

Dr. Citra Raditha, Sp.A. Jl. Pahanom No. 19, Buntok, Barito Selatan. Kalimantan Selatan. E-mail: citra_raditha@idai.or.id,c_raditha@yahoo. com
$\mathrm{I}$

nfeksi dengue merupakan infeksi Arbovirus tersering pada manusia. ${ }^{1}$ Insiden global dari infeksi dengue ini telah meningkat secara dramatis dalam beberapa dekade terakhir. ${ }^{1}$ Perjalanan penyakit 
sulit diperkirakan dan derajat penyakit bervariasi mulai dari yang bersifat asimtomatik sampai dengan demam berdarah dengue dengan perembesan plasma yang berakibat syok. ${ }^{2}$ Jika tidak ditangani baik, mortalitas dari komplikasi tersebut sebesar 20\% sedangkan jika dapat dideteksi lebih dini dan ditangani dengan baik, mortalitas berkurang menjadi $1 \% .^{3}$

Oleh sebab itu, akan sangat bermanfaat jika terdapat suatu parameter laboratorium tertentu yang dapat memperkirakan perjalanan penyakit dan komplikasi yang akan terjadi sehingga kasus-kasus tersebut dapat diberikan perhatian lebih. Beberapa parameter labarotorium tersebut meliputi perubahan jumlah trombosit, nilai hematokrit, jumlah leukosit dan limfosit plasma biru yang berperan dalam parameter perjalanan penyakit infeksi dengue. ${ }^{5}$ Penelitian ini mengombinasikan parameter darah tepi tersebut dalam menentukan hubungan dengan derajat infeksi dengue dan waktu turunnya demam (time offever defervescence) sehingga dapat diketahui derajat berat infeksi dengue dan komplikasinya.

\section{Metode}

Penelitian desain potong lintang untuk mengetahui hubungan antara kombinasi parameter laboratorium berupa trombosit, hemoglobin, hematokrit, leukosit, dan limfosit plasma biru dengan derajat infeksi dengue pada saat turunnya demam (defervescence). Sampel penelitian adalah anak usia 1-18 tahun dengan infeksi dengue yang dirawat di RSCM, RS Fatmawati, dan RS Harapan Kita. Kriteria eksklusi adalah sampel dengan infeksi bakteri dan kelainan yang dapat menyebabkan kelainan hematologi.

Pencatatan data meliputi identitas anak, riwayat penyakit, gejala klinis dan pemeriksaan fisis, laboratorium awal, dan tatalaksana. Tahap berikutnya adalah pemeriksaan parameter laboratorium berupa jumlah trombosit, nilai hematokrit, jumlah leukosit, dan jumlah limfosit plasma biru untuk tiap derajat infeksi dengue tiap hari. Sampel darah diperiksa di laboratorium 24 jam Bagian IKA Rumah Sakit Dr. Cipto Mangunkusumo (RSCM) dan RS jejaring, dan pembacaan slide dilakukan oleh dua analisis laboratorium secara tertutup di laboratorium 24 jam Bagian IKA RSCM. Pada demam hari ke-5 atau lebih, dilakukan pemeriksaan serologi $\mathrm{I}_{5} /$ $\mathrm{I}_{5} \mathrm{M}$ anti dengue (dengue blot). Hasil serologi dengue blot yang positif diikutsertakan sebagai subyek penelitian.

\section{Hasil}

Penelitian dilakukan sejak akhir bulan Desember 2010 hingga Mei 2011. Limapuluh satu anak dengan infeksi dengue dirawat di ruang perawatan IKA RSCM, dari jumlah tersebut 48 anak memenuhi kriteria inklusi. Pada ruang perawatan IKA Fatmawati, terdapat 50 anak mengalami infeksi dengue, 43 anak memenuhi kriteria inklusi. Sedangkan 10 anak dirawat di ruang perawatan IKA Harapan Kita, 9 anak memenuhi kriteria inklusi. Seluruh orangtua setuju anak diikutsertakan dalam penelitian. Total subjek 100 orang.

Subjek memiliki perbandingan sama antara anak laki-laki dan perempuan. Subjek terbanyak rentang usia 6-12 tahun (44\%). Sebagian besar subjek mengalami demam dengue (50\%), selebihnya mengalami demam berdarah dengue derajat I-II (30\%), dan sindrom syok dengue (20\%). Gejala klinis terbanyak ditemukan pada pasien adalah muntah, mual, nyeri kepala, nyeri perut, manifestasi perdarahan, mialgia, artralgia, dan nyeri retroorbital. Perbandingan gejala klinis tersebut berbeda pada tiap derajat infeksi dengue. Sebagian besar demam turun pada hari ke-4 (26\%), dan ke-5 (52\%).

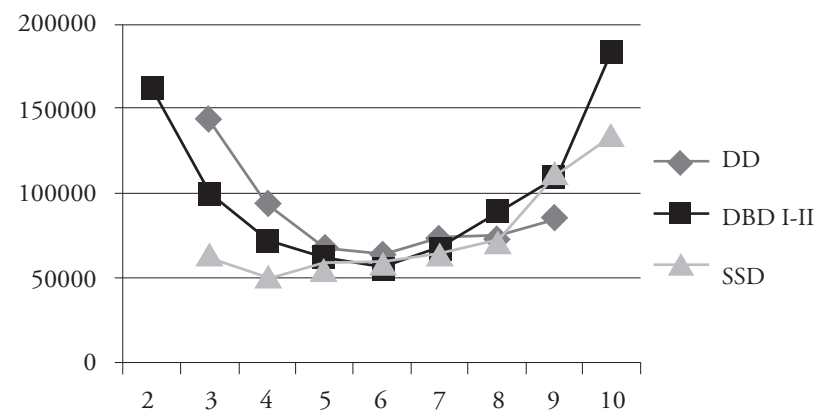

Gambar 1. Grafik perubahan trombosit pada perjalanan penyakit infeksi dengue

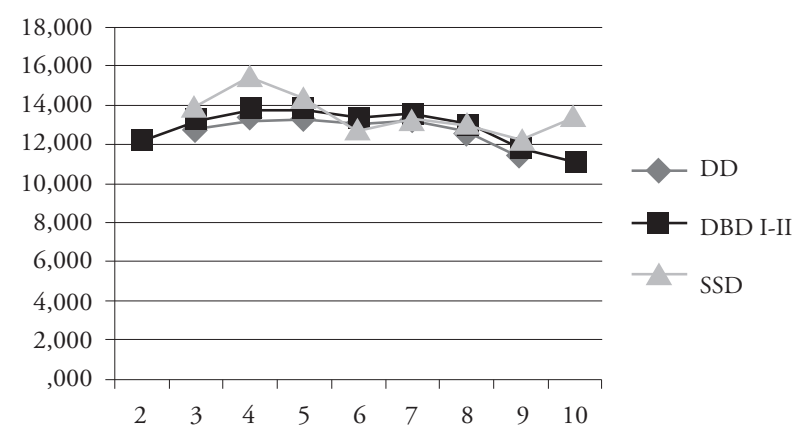

Gambar 2. Grafik perubahan hemoglobin pada perjalanan penyakit infeksi dengue 


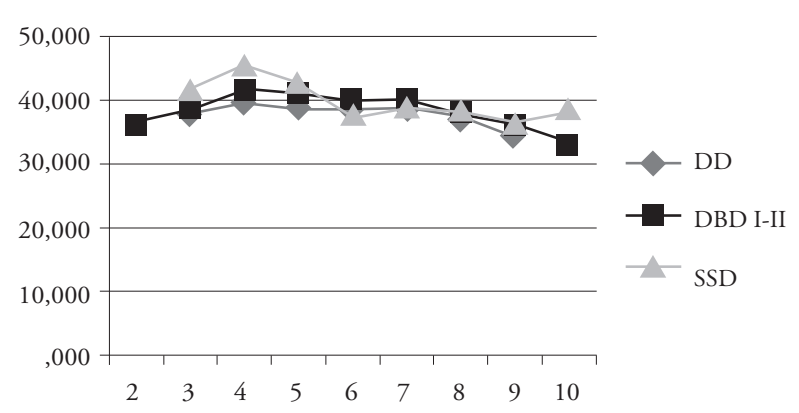

Gambar 3. Grafik perubahan hematokrit pada perjalanan penyakit infeksi dengue

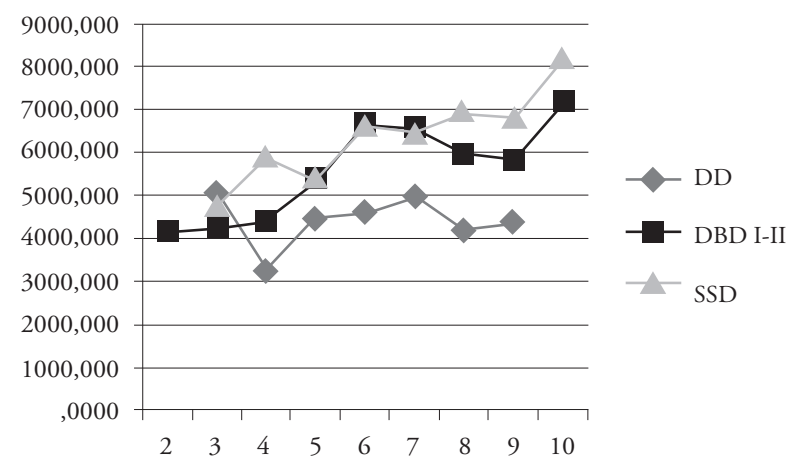

Gambar 4. Grafik perubahan leukosit pada perjalanan penyakit infeksi dengue

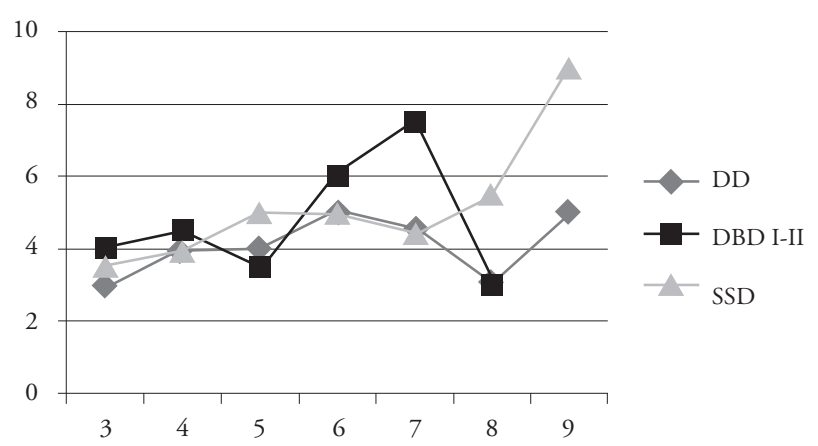

Gambar 5. Grafik perubahan limfosit plasma biru pada perjalanan penyakit infeksi dengue

Faktor yang berhubungan dengan derajat infeksi dengue pada saat demam turun (defervescence)

Pada analisis bivariat didapatkan bahwa jumlah trombosit pada SSD lebih lebih rendah secara bermakna dibandingkan dengan $\mathrm{DD}(\mathrm{p}<0,01)$ dan DBD I-II $(\mathrm{p}=0,032)$. Nilai hemoglobin pasien SSD lebih tinggi secara bermakna dengan $\mathrm{DD}(\mathrm{p}<0,001)$. Nilai hematokrit pada DD lebih rendah secara bermakna dengan DBD I-II $(\mathrm{p}=0,05)$ dan SSD $(\mathrm{p}<0,001)$. Jumlah leukosit pada DD lebih rendah secara bermakna dengan DBD I-II $(\mathrm{p}=0,036)$ dan SSD ( $\mathrm{p}=0,003)$. Jumlah limfosit plasma biru tidak memiliki perbedaan yang bermakna antara ketiga spektrum infeksi dengue.

Analisis multivariat yang digunakan adalah analisis diskriminan yang mendapatkan suatu persamaan $y=-6,089-0,020 x$ trombosit $\left(\right.$ dalam $\left.10^{3}\right)+0,152$ $\mathrm{x}$ hematokrit $+0,22 \mathrm{x}$ leukosit (dalam $\left.10^{3}\right)$. Pada saat demam turun (defervescence), pasien diprediksi mengalami DD jika memiliki nilai diskriminasi $-3,06047$ hingga $-0,20671$, DBD jika nilai diskriminasi $-0,25809$ hingga 0,78855 , dan SSD jika nilai diskriminasi 0,45226 hingga 2,80560 ..

\section{Pembahasan}

Didapatkan perbedaan jumlah trombosit lebih rendah adalah antara pasien SSD dibandingkan dengan pasien DD (rerata $68680 \pm 20950 / \mu \mathrm{L} ; \mathrm{p}<0,001)$ dan $\mathrm{DBD}$ derajat I-II (rerata $60275 \pm 22114 / \mu \mathrm{L} ; \mathrm{p}=0,032$ ) pada saat defervescence. Penelitian oleh Carlos $\mathrm{dkk}^{6}$ menyimpulkan bahwa jumlah trombosit pada pasien DBD lebih rendah secara bermakna (rerata $58500 \pm 84$ $100 / \mu \mathrm{L})$ dibandingkan dengan pasien DD (113 $800 \pm 58300 / \mu \mathrm{L} ; \mathrm{p}<0,05)$ pada saat defervescence namun pada penelitian Carlos $\mathrm{dkk}^{6}$ adalah pasien SSD tidak dipisahkan dari kelompok pasien DBD.

Analisis untuk nilai hematokrit pada penelitian kami ditemukan bahwa perbedaan hanya didapatkan antara nilai hematokrit pasien DD (median 40\% (35,6\%$45,2 \%)$ ), yang lebih rendah secara dibandingkan dengan pasien DBD derajat I-II (median 43\% (30\%$53 \%) ; \mathrm{p}=0,05)$ dan SSD (median 45\% (34\%-56\%); $\mathrm{p}<0,001)$ pada saat defervescence. Penelitian oleh Carlos $\mathrm{dkk},{ }^{6}$ menyatakan bahwa nilai hematokrit pada pasien DD lebih rendah dibandingkan dengan pasien DBD $(\mathrm{p}<0,001)$ pada saat defervescence.

Jumlah leukosit pada juga ditemukan perbedaan nilai leukosit pasien DD, yang lebih rendah dibandingkan dengan DBD derajat I-II dan SSD pada saat defervescence. Jumlah leukosit yang lebih tinggi pada pasien DBD derajat I-II dan SSD mungkin disebabkan oleh perembesan plasma yang cukup besar pada pasien dibandingkan pasien DD sehingga terjadi peningkatan leukosit secara relatif. Kepustakaan ${ }^{4}$ menyatakan bahwa pada syok berat, dapat dijumpai leukositosis 
dengan neutropenia absolut. Temuan tersebut sesuai dengan penelitian oleh Carlos $\mathrm{dkk},{ }^{6}$ yang menyatakan bahwa jumlah leukosit pada pasien DD lebih rendah secara bermakna dibandingkan dengan pasien DBD $(\mathrm{p}<0,005)$ pada saat defervescence. Terjadi depresi sumsum tulang pada infeksi dengue sehingga jumlah trombosit dan leukosit menurun di bawah jumlah normal.

Kami tidak menemukan perbedaan persentase jumlah limfosit plasma biru yang bermakna antara pasien DD, DBD derajat I-II, dan SSD. Hasil tersebut sesuai dengan penelitian Wells dkk. ${ }^{7}$ Sedangkan penelitian di Indonesia, dilaporkan bahwa jumlah limfosit teraktivasi meningkat lebih tinggi pada pasien SSD dibandingkan dengan non SSD $(\mathrm{p}<0,05) .{ }^{8}$ Penelitian-penelitian sebelumnya tidak dilakukan pada saat defervescence. Peningkatan limfosit plasma biru tersebut merupakan respons transformasi sel limfosit terhadap stimulasi antigen virus. ${ }^{7}$

Kelemahan pada persamaan diskriminan penelitian kami adalah terdapat sedikit nilai yang berhimpit sehingga kualitas persamaan diskriminans kurang akurat dalam membedakan diagnosis DD dengan DBD derajat I-II, serta diagnosis DBD derajat I-II dengan SSD. Hal tersebut dapat disebabkan oleh jumlah sampel yang tidak setara antara pasien DD, DBD derajat I-II, dan SSD dalam analisis multivariat ini. Oleh karena itu, menentukan diagnosis penting sekali untuk turut memperhatikan klinis pasien khususnya pada kegawatan syok pada diagnosis SSD, dan tidak semata-mata berpanduan dengan darah tepi.

Penelitian kami memiliki keterbatasan, setiap subjek penelitian tidak dirawat pada hari demam sama. Hal tersebut menyebabkan hasil deskriptif pola perubahan darah tepi pada tiap derajat infeksi dengue khususnya sebelum masa defervescence kurang menggambarkan yang sebenarnya. Penentuan hari demam pada tiap pasien dapat menimbulkan recal bias. Sampel pasien dengue pada penelitian kami dibagi menjadi 3 kelompok, yaitu DD, DBD derajat I-II, dan SSD, tetapi jumlah sampel tiap kelompok berbeda. Pembuatan preraparat apusan darah tepi dilakukan oleh orang yang berbeda dari rumah sakit yang berbeda sehingga dapat memengaruhi kualitas dari apusan darah tepi tersebut. Pengambilan darah tepi pada beberapa pasien SSD dilakukan bersamaan dengan loading cairan karena keadaan kegawatan saat itu. Hal tersebut dapat memengaruhi hasil darah tepi.

\section{Kesimpulan}

Terdapat hubungan antara kombinasi trombosit, hematokrit, leukosit dengan derajat berat infeksi dengue pada saat defervescence yang dirumuskan dalam persamaan $\mathrm{y}=-6,089-0,020 \mathrm{x}$ trombosit $\left(\right.$ dalam $\left.10^{3}\right)$ $+0,152 \times$ hematokrit $+0,22 \times$ leukosit $\left(\right.$ dalam $\left.10^{3}\right)$. Prediksi diagnosis DD jika memiliki nilai diskriminasi $-3,06047$ hingga $-0,20671$, DBD derajat I-II jika nilai diskriminasi -0,25809 hingga 0,78855, dan SSD jika nilai diskriminasi 0,45226 hingga 2,80560.

\section{Daftar pustaka}

1. World Health Organization. Dengue Haemorrhagic fever.: Diagnosis, treatment, prevention and control. $2^{\text {nd }}$ ed. Geneva: World Health Organization; 1997. h.128.

2. World Health Organization. Prevention and control of dengue and dengue haemorrhagic fever-comprehensive guidelines. Edisi ke-1. New Delhi: SEARO; 1999. h.1-21.

3. Narayanan M, Aravind MA, Ambikapathy P, Prema R, Jeyapau MP. Dengue fever-clinical and laboratory parameters associated with complication. Dengue Bull 2003;27:108-15.

4. Gatot D. Perubahan hematologi pada infeksi dengue. Dalam: Hadinegoro SRH, Satari HI, penyunting. Demam berdarah dengue naskah lengkap pelatihan dokter spesialis anak \& dokter spesialis penyakit dalam dalam tatalaksana kasus DBD. Jakarta: Balai Penerbit Fakultas Kedokteran Universitas Indonesia; 2000. h.45-7.

5. Azeredo E, Zagne SMO, Santiago MA, Gouvea AS, Santana AA, Neves-Souza PCF, dkk. Characterisation of lymphocyte response and cytokine pattern in patients with dengue fever. Immunobiol 2001;204:494-507.

6. Carlos CC, Oishi K, Cinco MTDD, Mapua CA, Inoue $S$, Cruz DJM, dkk. Comparison of clinical features and hematologic abnormalities between dengue fever and dengue hemorrhagic fever among children in the Philippines. Am J Trop Med and Hyg 2005;7:43540 .

7. Wells RA. Kinetics of peripheral blood leukocyte alterations in Thai children with dengue hemorrhagic fever. Infect Immun 1980;28:428-3.

8. Sulistyowati E. Aktivasi limfosit pada preparat darah hapus penderita demam berdarah dengue [Tesis]. Semarang: 2003: Departemen Ilmu Kesehatan Anak FK UNDIP, 2003. 